\title{
Scenario-based mission statements
}

\author{
Promoting sustainable urban development \\ in the context of the energy transition
}

\begin{abstract}
Raphael Dietz, Department of International Urbanism, Institute of Urban Planning and Design, University of Stuttgart,
Keplerstraße 11, 70174 Stuttgart (raphael.dietz@si.uni-stuttgart.de) (10 https://orcid.org/0000-0002-0025-3038

Dan Teodorovici, Department of International Urbanism, Institute of Urban Planning and Design, University of Stuttgart

(dan.teodorovici@si.uni-stuttgart.de) (1) https://orcid.org/0000-0002-3918-9635

Sigrid Busch, Department of International Urbanism, Institute of Urban Planning and Design, University of Stuttgart

(sigrid.busch@si.uni-stuttgart.de) (10 https://orcid.org/0000-0002-6647-8782

Markus Blesl, Institute of Energy Economics and Rational Energy Use, University of Stuttgart (markus.blesl@ier.uni-stuttgart.de)

Michael Ruddat, Center for Interdisciplinary Risk and Innovation Studies (ZIRIUS), University of Stuttgart

(michael.ruddat@zirius.uni-stuttgart.de) (1) https://orcid.org/0000-0002-9625-9062

Yvonne Zahumensky, Center for Interdisciplinary Risk and Innovation Studies (ZIRIUS), University of Stuttgart (yvonne.zahumensky@zirius.uni-stuttgart.de)
\end{abstract}

Using a planning process for the Stuttgart Neckar Valley as a case study, this paper analyzes the urban inertial forces that counteract the transformation of energy infrastructure areas in the context of the energy transition. In order to overcome these forces, a scenario-based mission statement was developed in which spatial scenarios were derived from energy scenarios and finally summarized in a concept plan for the Neckar Valley. The mission statement was developed following an analytical-deliberative and transdisciplinary approach. The approach to mission statement development presented here can respond flexibly to changing framework conditions and thus serve as a model for other cities with large-scale energy infrastructures in transition.

\section{Szenario-basierte Leitbilder}

Wie die Energiewende zur Förderung einer nachhaltigen

Stadtentwicklung genutzt werden kann

Am Beispiel eines Planungsprozesses für das Stuttgarter Neckartal wird analysiert, welche urbanen Beharrungskräfte einer städtebaulichen Transformation von Energieinfrastrukturflächen im Rahmen der Energiewende entgegenwirken. Um diese Kräfte zu überwinden, wurde ein szenariobasiertes Leitbild entwickelt, in dem auf Basis energiewirtschaftlicher Szenarien räumliche Szenarien abgeleitet und schließlich in einem Konzeptplan für das Neckartal zusammengeführt wurden. Zur Entwicklung des Leitbilds wurde ein analytisch-deliberatives und transdisziplinäres Vorgehen verfolgt. Der vorgestellte Ansatz der Leitbild-

This is an article distributed under the terms of the Creative Commons Attribution License CCBY 4.0 (https://creativecommons.org/licenses/by/4.0/)

https://doi.org/10.14512/tatup.301.29

Submitted: 17. 09.2020. Peer reviewed. Accepted: 02.02.2021 entwicklung kann flexibel auf sich verändernde Rahmenbedingungen reagieren und daher als Vorbild für andere Städte mit großmaßstäblichen Energieinfrastrukturen dienen, die sich im Rahmen der Energiewende verändern werden.

Keywords: energy transition, mission statement, scenario, urban inertial forces, integrated urban development

\section{Introduction}

In order to meet the global challenge of climate change, the German government has decided to implement the energy transition. In Stuttgart this has led to the transformation of large-scale energy infrastructure in the Neckar River Valley. This valley presents itself as a fragmented townscape: it is home to suburbanized villages, world class industry, energy and transport infrastructure, but offers very limited access to the river. The transdisciplinary research project WECHSEL ${ }^{1}$ investigated the opportunities arising from the transformation of energy infrastructures to bring Stuttgart closer to the river and to promote a sustainable and livable urban development with new neighborhoods and open spaces along the Neckar. Considering the amalgam of grown structures and their disparate urban inertial forces, it is clear that such a transformation would become a

1 German word for "change" and an acronym for: Advancing the energy structure in Stuttgart and resulting opportunities for sustainable urban development. 
true Herculean task. Therefore, WECHSEL coupled research, teaching, participation and communal policies of the City of Stuttgart. In an integrative approach, the energy sectors of electricity, heat and mobility were combined with urban planning to elaborate a vision of how Stuttgart can become a sustainable river city.

\section{Urban inertial forces}

Human settlements have always been subject to transformation, which has rarely been without difficulties. Scholars refer to the notion of "inertial forces" or "structural inertia" to point towards "resistance to change" (Hallowell 2013, p. 2): Urban inertial forces can manifest themselves in many ways, have many causes, and present challenges to the promoters of change. They do not result exclusively from local conditions, and may have to be resolved at regional or national level, but they have an inhibiting effect on local urban development. It is important to perceive them not only as obstacles, but also to acknowledge that they might be perfectly legitimate (e. g., resistance to eviction in case of urban renewal). They should therefore be carefully considered in transformation processes.

With regard to the historically evolved and complex Stuttgart Neckar Valley, the research team iteratively identified urban inertial forces of varying intensity, while applying various methods like structural analyses and collecting feedback from stakeholders. From the WECHSEL perspective, the most significant inertial forces arose from urban morphology, energy infrastructure, and societal and political aspects.

\section{Urban inertial forces resulting from urban morphology}

A vast part of the Stuttgart Neckar Valley consists of already constructed areas of which substantial parts are occupied by well-functioning enterprises. There, the partially disperse land ownerships complicate a transformation. Other areas are occupied by supply infrastructures (former waterworks, gas storage, the river are the responsibility of the federal government, which would require time-consuming negotiations. In addition, geological conditions must be considered, in particular the protection of Stuttgart's mineral springs.

\section{Urban inertial forces resulting from energy infrastructure}

The energy infrastructure located on several sites along the river Neckar supplies large parts of the city with electricity, gas and district heating. Due to this, supply security must be guaranteed during the entire transformation process. Alternatives must therefore be built up step by step and only then can the existing infrastructure be dismantled. In this context, the underground infrastructure also plays an important role - for example, complex supply networks for district heating and water, for which important main lines and nodes run in the planning area and which must also be converted or reused. The creation of these structures required high investments, which would also be true for their transformation. In contrast, the profits that can be achieved - such as an improved quality of life for all Stuttgart's citizens, for example by granting access to the river, creating new recreational areas, or increasing biodiversity - are difficult to convert into concrete monetary amounts.

\section{Urban inertial forces resulting from societal aspects}

Research has shown that "[...] positive emotional bonds between people and valued environments [...]" (Devine-Wright 2007 , p. 7) are often central when it comes to structural changes in the nearby environment. Some residents have a certain picture of this environment in mind and are therefore resistant to change (Pasqualetti 2001). One example of unwanted change are wind farms (Sonnberger and Ruddat 2017). They may have negative visual effects on the landscape in the eyes of residents and this is often reported as a very important factor for attitude formation as well as protest against the renewable energy infrastructure (Jones and Eiser 2010). Another important societal aspect is the interaction between the planning authorities and the affected population. If residents perceive the planning process as

\section{Urban inertial forces may be perfectly legitimate and should therefore be carefully considered in transformation processes.}

power plants), which are owned by a single company and are already undergoing partial transformation. These areas are also home to some listed buildings which prevent a completely free reorganization, but simultaneously offer the chance to create identity for new quarters that could be developed on the sites. At the same time huge traffic infrastructures such as motorways and the status of the river Neckar as federal waterway are core obstacles to urban improvement, because any change or relocation requires considerable investments. Also, the highway and unfair, resistance can be a probable outcome. Also mistrust in key actors (e. g., local agencies, politicians, big energy companies) can play a crucial role in the evaluation of new energy developments (Sonnberger and Ruddat 2017).

Urban inertial forces resulting from political aspects

There are at least three political aspects which are of special interest in the case of WECHSEL. First, missing clear political guidelines lead to a lack of planning security on the part of 
energy companies, which therefore inhibit the release of underused areas for urban development in order to keep them as reserve areas. Second, ideology can prevent change. In the case of Stuttgart, the mobility infrastructure in the Neckar Valley is the result of political decisions that followed the former vision of a car-friendly city. The current discussion on how to overcome these dependencies (Ruddat and Sonnberger 2013) is crucial for the handling of the federal highway and thus access to the river. Thirdly, the ambiguity of the administration has to be taken into account. On the one hand, central aspects of classic narios deal with the question of how a desired target state can be achieved. This definition expresses the interdependence of normative scenarios and mission statements. Normative scenarios require a known target state, which they can help to achieve. Mission statements, in return, require a sound basis that enables a desired future state to be achieved. If the mission statement contains ambitious, high-level goals that cannot be achieved while maintaining the current development trend, then the mission statement must be backed up by scenarios that break the previous trend (Börjeson et al. 2006).

\section{Normative scenarios reflect the ambitious goal of the transformation process in the Neckar valley towards climate neutrality and revitalization of riparian zones.}

bureaucracy like clear hierarchies and responsibilities, expert knowledge or rule orientation lead to a relatively high technical efficiency (Weber 1980). On the other hand, this may take some time. Especially in big towns like Stuttgart, urban planning processes are often very complex and may affect many departments and different responsibilities. Coordination is needed, which can further slowdown or even stop the whole process.

\section{Scenario-based mission statement: a concept plan for the Stuttgart Neckar Valley}

In order to overcome these inertial forces WECHSEL has coupled two planning instruments that have been used for decades in the context of sustainable development (Wack 1985; Becker et al. 1998): mission statement and scenarios.

While mission statements ${ }^{2}$ focus on a certain target state that is to be achieved based on normative assumptions (Albert et al. 2019), scenarios are more often used to develop and describe a variety of alternative futures that can be derived from different transformation paths (Schoemaker 1993). However, both instruments stand for a strategic approach to urban transformation processes in which social, cultural, ecological, political and economic objectives can be integrated into holistic visions (Potschin et al. 2010).

Börjeson et al. (2006) distinguish three types of scenarios: predictive, explorative and normative scenarios. Predictive scenarios describe the effects of framework conditions such as climate change or demographic developments by forecasting them as plausibly as possible. Explorative scenarios examine the effects of certain changes within this framework. Normative sce-

2 In the planning literature, instead of the term mission statement, the German term "Leitbild" is sometimes used (Potschin et al. 2010).
Because WECHSEL was initiated in 2017 with the ambitious goal of supporting the transformation process towards climate neutrality and the revitalization of the riparian zones along the Neckar, the focus lay on the development of normative scenarios. These scenarios were used to show ways to reach the goal of implementing the German energy transition strategy while at the same time regaining the river banks of the Neckar as high-quality settlement and landscape areas.

\section{The two spatial scenarios and their role towards the mission statement}

Based on Stuttgart's "Masterplan 100\% Climate Protection" (Fraunhofer IBP 2017) - where the City of Stuttgart describes a pathway to climate neutrality until 2050 - WECHSEL makes proposals for efficient energy transition pathways. In order to quantify future space requirements for the local energy supply and distribution system, an energy system analysis was carried out for the city of Stuttgart using TIMES Local (a linear optimization model). Then, the economic and secure structure of the energy supply was determined and analyzed in a scenario analysis. For this purpose, a base scenario was defined without specifying energy or climate targets. Starting in 2020, additional climate protection targets $\left(95 \%\right.$ reduction of $\mathrm{CO}_{2}$ until 2050 in comparison to 1990) were specified in the second scenario based on the basic scenario. In addition, a third scenario examined the impact of a shift in traffic from road to rail and from motorized individual traffic to local public transport.

Using these energetic scenarios, assumptions were derived regarding the chronological order of the availability of sites for future development, which are covering a time horizon of more than 30 years. On the basis of this knowledge, two spatial scenarios were developed that made positive use of the uncertainty about future space availability and integrated many suggestions and ideas that emerged from various participation processes, which will be explained further on. 


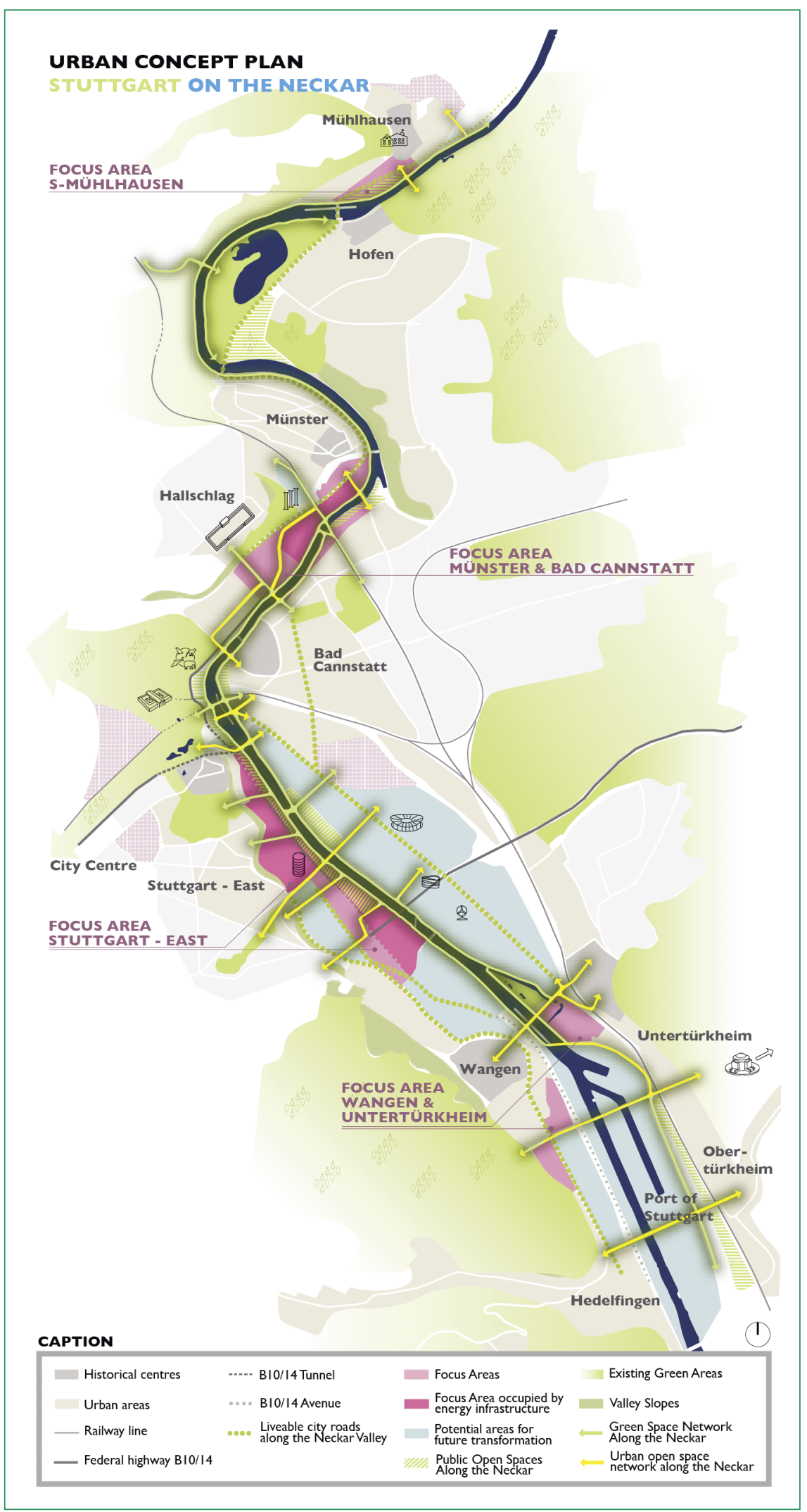

Fig.1: Urban concept plan for the Stuttgart Neckar Valley (reduced representation). Source: modified from WECHSEL (in press, p. 85)
The first scenario, Modification, assumes that no alternative energy infrastructure areas will be available in the near future. The central feature of this scenario is the retention of the existing basic order, meaning that essential infrastructures are retained in their current form over a longer period of time. Urban development options aim primarily at transforming specific locations or sub-areas as well as establishing and upgrading connections. With regard to areas that are particularly relevant in terms of urban development, concepts have been developed that allow for the integration of energy infrastructures into new urban and landscape elements.

The second scenario, Transformation, is based on the assumption that alternative energy infrastructure areas can be found in and around Stuttgart. This frees up large contiguous areas on the Neckar. In this scenario, the area of the former gas works plays a special role. A strategically located new neighborhood with access to the Neckar could be developed, integrating and opening up former elements of the gas works as monuments of the industrial heritage. Further on, this scenario considers successful negotiations with property owners in the southern Neckar Valley and positive developments in the direction of climate-friendly mobility, so that parts of the federal highway can be relocated or converted into a city street.

These spatial scenarios were discussed with numerous stakeholders and the essence of this discourse was incorporated into a preliminary version of a concept plan for the Stuttgart Neckar Valley (see fig. 1), which supplements the municipal "Landscape Masterplan Neckar" (Landeshauptstadt Stuttgart 2017). For the first time, the concept examines Stuttgart's Neckar Valley in its entirety, presents new perspectives for some areas and makes suggestions as to where new neighborhoods could be created. These neighborhoods should be developed in participatory processes, that focus on mixed use and sustainable forms of mobility, and that offer high-quality public spaces which relate to the river. The neighborhoods support ecological con- 


\begin{tabular}{|c|c|c|c|c|}
\hline Idea/aspect & $\begin{array}{l}\text { WECHSEL- } \\
\text { Consortium } \\
\text { (science) }\end{array}$ & $\begin{array}{l}\text { WECHSEL-Consortium } \\
\text { (City of Stuttgart) }\end{array}$ & $\begin{array}{l}\text { Civil society } \\
\text { (citizens) }\end{array}$ & $\begin{array}{l}\text { Stakeholder (Professional } \\
\text { audience, organized } \\
\text { affected persons) }\end{array}$ \\
\hline Relocation of federal highway/design as a Boulevard & $x$ & $x$ & & \\
\hline $\begin{array}{l}\text { Area gas works: Development of a livable neighborhood } \\
\text { at the Neckar; culture, sports, leisure }\end{array}$ & $x$ & $x$ & $x$ & \\
\hline Logistics area: Mixed-use public campus & $x$ & $x$ & $x$ & \\
\hline Waterworks establishes itself as a public cultural campus & $x$ & $x$ & $x$ & \\
\hline $\begin{array}{l}\text { Industrial area south of the waste-to-energy plant: } \\
\text { developing into an element of the city on the river }\end{array}$ & $x$ & $x$ & & \\
\hline "Blue S" and "Neckartrauf": Hofener Straße as esplanade & $x$ & $x$ & $x$ & \\
\hline $\begin{array}{l}\text { Traffic/mobility: mobility hubs, city logistics center, expansion } \\
\text { of the bicycle and public transport network }\end{array}$ & $x$ & & $x$ & $x$ \\
\hline
\end{tabular}

Tab.1: Matrix showing which idea comes from which actor (Excerpt).

cerns and contribute to the city's energy production. Originally, the concept plan was to become an official plan in itself, but in the meantime the City of Stuttgart has decided to draw up a new urban development concept for the entire city in which the concept plan is to be incorporated.

A particular challenge of this approach was to interlink the quantitatively oriented energetic scenarios with the qualitatively oriented participatory urban planning modeling. This interlinking was achieved through an analytical-deliberative and transdisciplinary process.

\section{How the mission statement was developed}

Nowadays, people want to and should be involved in decisions that affect their daily lives (Nanz and Fritsche 2012) - especially if they are as far-reaching as the changes aimed for in the concept plan for the Stuttgart Neckar Valley. The analytical-deliberative approach (National Research Council 1996) is a tried and tested way to meet the criteria of "good participation" - referring to concepts such as respect, openness or transparency (Arbter 2011; Brettschneider 2011). The approach focuses on the integration of expert and laypeople knowledge as well as judgements of these actors. The analytical part of the approach encompasses the rule-based clarification of open questions concerning facts. As Renn puts it: "Analysis in this context means the use of systematic, rigorous and replicable methods to formulate and evaluate knowledge claims" (Renn 2004, p. 292).

One example of decisions that affect people's lives could be the impacts of the German Energy Transition on the urban region of Stuttgart. How big is the potential for renewables and how can it best be realized with respect to economic, ecological, political and social conditions? There are many different actors that can contribute to the possible answer(s). On the one hand, scientists, risk managers, engineers etc. deal with the relationships of cause and effect as well as means and ends. On the other hand, residents, members of the municipal council, action groups etc. are very familiar with the circumstances and history of the local situation and are capable of reporting on the possible positive and negative effects of the various options (Renn 2004). Normally, there is not a single answer or an ideal option that fits the expectations of all stakeholders and/or the public. This is where deliberation starts. The deliberative part of the approach deals with the communicative exchange of arguments about the different options. This takes the form of a rational discourse among all stakeholders involved to arrive at a mutual understanding, and finally rational decision making.

The WECHSEL participation formats (2017-2019) were structured accordingly in two citizens' workshops, two stakeholder workshops and one expert workshop. Experts, stakeholders and citizens had fair and equal chances to offer their opinions during the workshops. The workshop organization focused on the possible maximisation of interaction and exchange of arguments among participants. It also sought to transfer decisive input from one event to the other and to integrate as much as possible of the diverse and rich results into the ongoing research process.

The research team used the intermediate workshop results for a first draft of the mission statement, containing the two scenarios about how the Neckar Valley could be developed. Both scenarios were then discussed at the second stakeholder workshop. In parallel, various workshops were held with the city administration. Feedback was beneficial for improving the mission statement draft. This updated draft was discussed at the expert workshop, and then further improved by final adjustments. It has to be reflected and made transparent that the scientists were actors in the development of the mission statement and thus in the transformation process (Lösch et al. 2016, p. 16; Lösch 2017). Not all ideas could be equally considered, and the transdisciplinary research team acted as a "filter" that finally decided, in consultation with the city administration, which points should be included in the concept. For the sake of transparency, a ma- 
trix (tab. 1) was created that shows which ideas from which actor were incorporated into the mission statement (WECHSEL in press, p. 118-119).

\section{Conclusion}

The WECHSEL case study shows that the transformation of urban energy infrastructure in the context of the energy transition has a significant potential for transforming such areas into integrated areas of the city, with new livable urban quarters and open spaces. This is particularly true for Stuttgart, but is also relevant for other cities with power plant locations. WECHSEL was also faced with the challenge that in the course of such transformations one has to deal with a complex mélange of urban inertial forces. While some of these inertial forces are specific to the Stuttgart context (e.g., mineral springs), others will also be relevant to similar cases (e. g., underground supply structures, land ownership). The handling of these different inertial forces calls for a transdisciplinary approach - with all its challenges. With WECHSEL these challenges proved to be fruitful friction. Controversies within the project had mostly led to a synthesis with co-designed scenarios and pathways for a sustainable development of the urban infrastructure along the Neckar River Valley as an output (Dietz et al. in press).

The presented approach of the scenario-based mission statement takes into account that future developments are difficult to predict and for that reason provides a goal area on which future planning can be based. The transformation scenario assumes significantly more far-reaching changes, with correspondingly large effects on the urban structure. It is therefore counteracted by urban inertial forces to a much greater extent, which makes

\section{The handling of different urban inertial forces calls for a transdisciplinary approach.}

intense efforts necessary to realize the scenario. In contrast, the modification scenario represents a compromise. It is easier to implement, but also leaves a lot of potential for urban development untapped. In order to use the advantages of the two scenarios and to reduce the disadvantages, they were finally merged into a concept plan. The concept plan can provide decisive supportive arguments for local decision makers such as the municipal council who finally decides on urban development measures or the energy company as owner of the areas to work on the transformation process.

The analytical-deliberative approach helps to identify the major urban inertial forces and involves actors and stakeholders in the solution finding process from the very beginning. This results in a higher legitimacy and a higher acceptance of the transformation, thus increasing the probability of implementation.

If scenario-based mission statements are supposed to become a role model for future change in complex urban situations, the process of their implementation has to be carefully considered. It should be noted that this process must be transdisciplinary and long-term and contain separate steps to adapt to changing framework conditions.

\section{Funding declaration}

Research for this publication was funded by the German Federal Ministry of Education and Research through the project WECHSEL.

\section{References}

Albert, Christian; von Haaren, Christina; Klug, Hermann; Weber, Raphael (2019): Leitbilder and scenarios in landscape planning. In: Christina von Haaren, Andrew Lovett and Christian Albert (eds.): Landscape planning with ecosystem services. Theories and methods for application in Europe. Dordrecht: Springer, pp. 423-433. https://doi.org/10.1007/978-94-024-1681-7_27

Arbter, Kerstin (2011): Standards der Öffentlichkeitsbeteiligung. Praxisleitfaden. Wien: Bundesministerium für Land- und Forstwirtschaft, Umwelt und Wasserwirtschaft (Lebensministerium)

Becker, Heidede; Jessen, Johann; Sander, Robert (eds.) (1998): Ohne Leitbild? Städtebau in Deutschland und Europa. Stuttgart: Karl Krämer Verlag.

Börjeson, Lena; Höjer, Mattias; Dreborg, Karl-Henrik; Ekvall, Tomas; Finnveden, Göran (2006): Scenario types and techniques. Towards a user's guide. In: Futures 38 (7), pp.723-739. https://doi.org/10.1016/j.futures.2005.12.002

Brettschneider, Frank (2011): Kommunikation und Meinungsbildung bei Großprojekten. In: Aus Politik und Zeitgeschichte 61 (44-45), pp. 40-47. Devine-Wright, Patrick (2007): Reconsidering public attitudes and public acceptance of renewable energy technologies. A critical review. Manchester: Manchester Architecture Research.

Dietz, Raphael; Busch, Sigrid; Teodorovici, Dan (in press): Conflicts as catalytical elements in transdisciplinary knowledge production. Recommendations based on the research project "WECHSEL" In: Trialog (137).

Fraunhofer IBP (2017): Masterplan $100 \%$ Klimaschutz der Landeshauptstadt Stuttgart. Available online at https://www.stuttgart.de/medien/ibs/EntwurfMasterplan-100-Klimaschutz.pdf, last accessed on 11.01.2021.

Hallowell, George (2013): Understanding structural inertia. Examining suburban morphology and patterns of persistence and change. Raleigh, North Carolina: North Carolina State University. Available online at http://www.lib.ncsu.edu/ resolver/1840.16/8414, last accessed on 22.12.2020.

Jones, Christopher; Eiser, Richard (2010): Understanding 'local' opposition to wind development in the UK. How big is a backyard? In: Energy Policy 38 (6), pp.3106-3117. https://doi.org/10.1016/j.enpol.2010.01.051

Landeshauptstadt Stuttgart (2017): Erlebnisraum Neckar. Ein Masterplan für Stuttgart als Stadt am Fluss. Stuttgart: Landeshauptstadt Stuttgart. Lösch, Andreas (2017): Technikfolgenabschätzung soziotechnischer Zukünfte. Ein Vorschlag zur wissenspolitischen Verortung des Vision Assessments. In: TATUP - Journal for Technology Assessment in Theory and Practice 26 (1-2), pp. 60-65. https://doi.org/10.14512/tatup.26.1-2.60

Lösch, Andreas et al. (2016): Technikfolgenabschätzung von soziotechnischen Zukünften. In: ITZ Diskussionspapiere, Nr. 03. Karlsruhe: KIT. 
Nanz, Patrizia; Fritsche, Miriam (2012): Handbuch Bürgerbeteiligung. Bonn: Bundeszentrale für politische Bildung.

National Research Council (1996): Understanding risk. Informing decisions in a democratic society. Washington, DC: The National Academies Press. https://doi.org/10.17226/5138

Pasqualetti, Martin (2001): Wind energy landscapes. Society and technology in the California desert. In: Society \& Natural Resources 14 (8), pp. 689-699. https://doi.org/10.1080/08941920117490

Potschin, Marion; Klug, Hermann; Haines-Young, Roy (2010): From vision to action. Framing the Leitbild concept in the context of landscape planning. In: Futures 42 (7), pp. 656-667. https://doi.org/10.1016/j.futures.2010.04.003

Renn, Ortwin (2004): The challenge of integrating deliberation and expertise. Participation and discourse in risk management. In: Timothy McDaniels and Mitchell Small (eds.): Risk analysis and society. An interdisciplinary characterization of the field. Cambridge: Cambridge University Press, pp. 289-366. https://doi.org/10.1017/CB09780511814662.009

Ruddat, Michael; Sonnberger, Marco (2013): Stellplätze, Service und Flexibilität. Vorschläge zur Verbesserung des Car- und Bikesharing aus Kundensicht. In: Marco Sonnberger, Diana Gallego Carrera and Michael Ruddat (eds.): Teilen statt Besitzen. Analysen und Erkenntnisse zu neuen Mobilitätsformen. Bremen: Europäischer Hochschulverlag, pp. 119-135.

Schoemaker, Paul (1993): Multiple scenario development. Its conceptual and behavioral foundation. In: Strategic Management Journal 14 (3), pp. 193-213. https://doi.org/10.1002/smj.4250140304

Sonnberger, Marco; Ruddat, Michael (2017): Local and socio-political acceptance of wind farms in Germany. In: Technology in Society 51, pp. 56-65. https://doi.org/10.1016/j.techsoc.2017.07.005

Wack, Pierre (1985): Scenarios. Uncharted waters ahead. In: Harvard Business Review 63 (5), pp. 73-89.

Weber, Max (1980): Wirtschaft und Gesellschaft. Grundriss der verstehenden Soziologie. Tübingen: Mohr.

WECHSEL (in press): Weiterentwicklung der bestehenden Stuttgarter Energieinfrastruktur und resultierende Chancen für die nachhaltige Stadtentwicklung (WECHSEL). Endbericht. Stuttgart: WECHSEL.

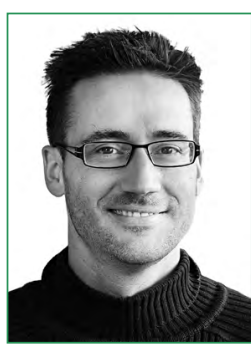

\section{RAPHAEL DIETZ}

works as a Research Associate at the Institute of Urban Planning and Design, University of Stuttgart and as an Architect and Urban Planner at 'asp' Architekten GmbH Stuttgart. His scientific work focuses on sustainable urban transformation, following a transdisciplinary approach.

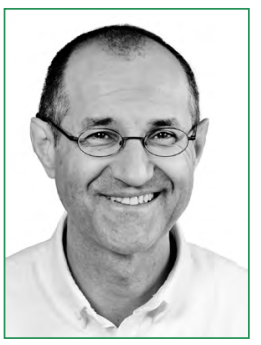

\section{DR. DAN TEODOROVICI}

is a Senior Researcher and Lecturer at the Institute of Urban Planning and Design, Department of International Urbanism, University of Stuttgart, Germany. $\mathrm{He}$ is also working as an independent Architectural and Planning Historian, Author and Exhibition curator.

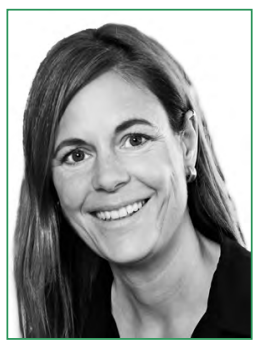

\section{DR. SIGRID BUSCH}

is a Senior Researcher, Lecturer and Architect at the Institute of Urban Planning and Design, Department of International Urbanism, University of Stuttgart, Germany. The focus of her work is on urban governance as well as on digital tools for simulation and visualization in urban planning to support stakeholder involvement.

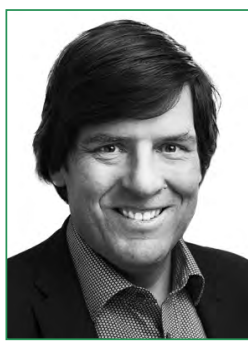

\section{PD.DR.MARKUS BLESL}

is Head of the Department System Analytical Methods and Heat Market (SAM) at the Institute for Energy Economics and Rational Energy Application (IER) at the University of Stuttgart. His main areas of work include the analysis and evaluation of energy technologies for coupled and uncoupled power and heat generation, and the development and application of energy system models.

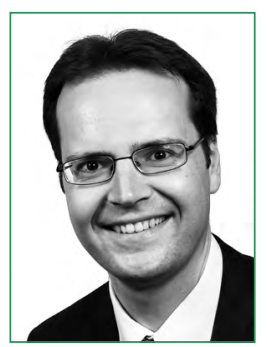

\section{DR. MICHAEL RUDDAT}

studied Political Science and Sociology at the University of Stuttgart. Since September 2012 he has been a Researcher at the Stuttgart Research Center for Interdisciplinary Risk and Innovation Studies (ZIRIUS, University of Stuttgart). His main fields of interests are risk perception and risk communication, sociology of technology, energy research and participation.

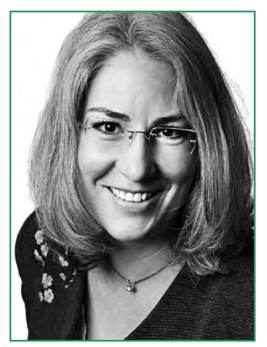

\section{YVONNE ZAHUMENSKY}

studied Geography, Political Science, Educational Science and Agricultural Sciences at the Universities of Tübingen, Hohenheim and Rio de Janeiro. Since 2017 she works as a Research Associate at ZIRIUS. Her work focuses on stakeholder participation and participatory technology assessment. 